\title{
Weight gain in relation to night work among nurses
}

\author{
Elaine C Marqueze ${ }^{\mathrm{a},{ }^{*}}$, Lucia C Lemos ${ }^{\mathrm{a}}$, Nilson Soares ${ }^{\mathrm{a}}$, Geraldo Lorenzi-Filho ${ }^{\mathrm{b}}$ and Claudia R.C. \\ Moreno $^{\mathrm{a}}$ \\ ${ }^{a}$ Departamento de Saúde Ambiental, Faculdade de Saúde Pública, Universidade de São Paulo, Av. Dr. Arnaldo, \\ 715, Zip Code 01246-904, São Paulo, SP, Brazil \\ ${ }^{\mathrm{b}}$ Instituto do Coração - InCor - Universidade de São Paulo, Av. Dr. Enéas de Carvalho Aguiar, 44, Zip Code \\ 05403-900, São Paulo-SP, Brazil
}

\begin{abstract}
Objective: To investigate the relationship between working at night and increased body weight in nursing. In addition, we evaluated the differences in the proportion of variables sociodemographic, work and health, according to the work shift and their association with body mass index. Methods: Based on questionnaires, we obtained data from 446 nursing professionals about aspects of their job, health and lifestyle. We performed linear and logistic regression analysis. Results: Working at night is associated with a weight gain greater than $(\beta=0.24$ $\left.\mathrm{kg} / \mathrm{m}^{2}\right)$ working during the day $\left(\beta=0.15 \mathrm{~kg} / \mathrm{m}^{2}\right)$, as well as with aging $\left(\beta=0.16 \mathrm{~kg} / \mathrm{m}^{2}\right)$ and duration of working in nursing $\left(\beta=0.18 \mathrm{~kg} / \mathrm{m}^{2}\right)$. Night workers have a higher educational level, have been working for more years in nursing and also in the current shift, do not have diabetes and have reported longer sleep than day workers. There are also a higher number of smokers among the night workers than day workers. Logistic regression analysis also showed the more time to work in nursing and as an assistant was more likely to develop overweight/obesity. Conclusion: Working at the night contributes to more weight gain than the day shift, aging and duration of working in nursing.
\end{abstract}

Keywords: shift work, weight gain, nursing professionals, night work, body mass index.

\section{Introduction}

Shift and night workers represent about $20 \%$ of the workforce of the European community [34] and also the United States [15]. Fischer [12] estimates that in Brazil, this percentage reaching $15 \%$ of the workforce. Schemes of work that alter the organization of work and sleep schedules of the individual can produce fatigue, mental irritability, tendencies toward depression, disturbances in appetite, intestinal organs and also in sleep [14].

Night work is usually associated with reduced duration and quality of sleep. In recent researches an association between sleep and obesity has been observed $[4,7,16,21-22,24-25,30]$, where the low quality and short duration of sleep are closely related to weight gain.

However, obesity is a multifactorial syndrome in which disorders of energy balance, resulting from temporal desynchronization with the biological temporal organization, may have an important and decisive role in its genesis. Some authors suggest that chronic desynchronization of circadian rhythms, as observed among shift workers, can affect energy metabolism and body weight regulation, promoting the development of obesity [10-11,31].

Karlsson et al [19] present that not only the sleep reduction, but also its change associated with the circadian desynchronization is associated with obesity. In animal models, Salgado-Delgado et al [28] found that obesity was caused by food intake during the rest

*Corresponding author. Phone + 5511 3061-7905. E-mail: ecmarqueze@usp.br 
phase, in which the change in food intake for the phase of normal activity prevented the increase in body weight. In summary, it can be concluded that eating habits can induce or prevent obesity.

Specifically in relation to nursing work, in which evening and irregular work hours are commonly observed, the scientific evidence is clear that shows that this organization of work can negatively affect the worker as much physiologically as psychologically [2]. Among the most frequent are sleep disorders and other health problems [17], such as coronary heart disease and stroke [5], in addition to accidents at work [6], decreased job performance and job satisfaction [2]. Zverev and Misiri [37] found among nursing professionals that this association persists for days off, indicating the accumulation of fatigue.

Considering that shift work leads to circadian misalignment and this, in turn, seems to be associated with obesity, our hypothesis in this study was that night work leads to increased body weight nursing staff higher than day work. This study aimed to investigate the relationship between working at night shift and increased body weight in nursing. In addition, we evaluated the differences in the proportion of variables sociodemographic, work and health, according to the work shift and their association with body mass index.

\section{Material and methods}

\subsection{Design / participants}

We conducted an epidemiological cross-sectional study with 941 nursing professionals from a public hospital. It was included on the study all the professionals who agreed to participate voluntarily in this research, a total of 548 people. Table 1 shows the comparison analysis of the losses of the population with the research group.

Table 1 - Test of proportions $(\chi 2)$ of the population studied and losses, by sex and work position.

\begin{tabular}{|c|c|c|c|c|}
\hline Variables & Categories & $\begin{array}{l}\text { Partici- } \\
\text { pants } \\
\qquad n(\%)\end{array}$ & $\begin{array}{l}\text { Loss } \\
\text { n }(\%)\end{array}$ & p \\
\hline Sex & $\begin{array}{l}\text { Female } \\
\text { Male }\end{array}$ & $\begin{array}{l}475(86.7) \\
73(13.3)\end{array}$ & $\begin{array}{l}332(84.7) \\
60(15.3)\end{array}$ & 0.39 \\
\hline $\begin{array}{l}\text { Work } \\
\text { position }\end{array}$ & $\begin{array}{l}\text { Nurse } \\
\text { Technician } \\
\text { or Nurse } \\
\text { Auxiliary }\end{array}$ & $\begin{array}{l}155(28.4) \\
391(71.6)\end{array}$ & $\begin{array}{l}117(29.8) \\
276(70.2)\end{array}$ & 0.65 \\
\hline
\end{tabular}

No statistically significant differences were found between the two groups regarding gender and function $(\mathrm{p}>0.05)$, showing that the groups are similar.

Of the 548 professionals, $68(12.4 \%)$ were excluded because they were male and a small proportion of the female population and $34(6.2 \%)$ were excluded because they had worked less than four months at the studied site. The remaining total of 446 nursing professionals $(47.4 \%$ of the population) was distributed in the following proportions: $30.9 \%$ nurses, 69.1\% nursing assistants (nurse technician and nurse auxiliary).

The mean age was 34.8 years (SD 9.5 years), the average working time in nursing was 9.5 years (SD 7.5 years), mean 4.5 years (SD 4.9 years) on the day shift and 6 years (SD 5.2 years) on the night shift.

\subsection{Working conditions}

Nurses working in different shifts and are classified according to the schedule of shifts, which are:

- Day shift - To work between 07:00 and 19:00h. It could be to work either morning shift or afternoon shift, or both. Working hours reported by 279 nurses were 6 hours/day (5 day-work x 2 day-off or 6 daywork $\mathrm{x} 1$ day-off), 8 hours/day (5 day-work x 2 dayoff or 6 day-work x 1 day-off), or 12 hours/day (12hours on duty x 36-hours off). Out of 279, 21 had a second job.

- Night shift - To work between 19:00 and 07:00h.

The working system was referenced to 12-hour on duty per 36-hour off ( $n=166$ nurses). A total of 27 nurses had a second job.

The second job was only used as an adjustment variable in linear regression analysis.

\subsection{Data collection}

For data collection, nursing professionals filled out a questionnaire on sociodemographics, work, health and lifestyle. Epworth questionnaire [18] was used in this study to evaluate sleepiness and the Occupational Stress Indicator (OSI) to estimate job satisfaction [27]. The OSI job satisfaction scale consists of twenty-two psychosocial aspects of work, resulting in a total score ranging from 22 to 132 points. The scale has no cutoff pre-defined for this study and was defined as high and low job satisfaction relative to the median (83.5 points). To calculate body mass index, we used self-reported body mass $(\mathrm{kg})$ and height $(\mathrm{m})$. Dekkers et al [9] present that self-reported body weight and height are valid measures in epidemiolog- 
ical cross-sectional study, as is the case this study. The calculation and BMI classification followed the criteria of the World Health Organization/WHO [1]. Sleep duration and body weight in the last year were self- reported by the nurses. The information of the actual number of disease was obtained through the Work Ability Index (WAI) [35].

\subsection{Ethical considerations}

The research project was approved by the Ethics Committee of the Faculty of Medicine, University of São Paulo. After approval, we conducted a pilot study on the adequacy of the questionnaires and then started to collect data during the working hours of participants. Data collection was performed at the target hospital during working hours.

\subsection{Data Analysis}

We performed descriptive statistics on the independent and dependent variables. To test the normality of the variables we used the Kolmogorov-Smirnov test.

We used the Pearson's Chi-square test $\left(\chi^{2}\right)$ or Fisher's Exact Test to compare proportions, and Student's t-test or Mann-Whitney test to compare continuous variables. Univariate and multiple logistic regressions were used to analyze the independent variables with overweight and obesity (stepwise forward technique). The consistency of the models was verified by the Hosmer-Lemeshow Goodness-of-Fit Test.

Analysis was performed using univariate and multiple linear regressions with body mass index (BMI) as the dependent variable, with the $\beta$ coefficients estimated at a confidence interval of $95 \%$. Five models were constructed using multiple linear regression, taking as independent variables age, time working in nursing, working hours in the day shift, working hours on the night shift and duration of self-reported sleep, all adjusted for smoking, physical activity level, educational level, marital status and second job.

In all tests were considered significant when $\mathrm{P}<0.05$. All data analysis was carried out with software SPSS, version 17.0 (SPSS Inc. Chicago, USA) and Stata, version 9.1 (Stata corp, Texas, USA).

\section{Results}

Night workers working in nursing for a mean time of 10.4 years (95\% CI 9.3-11.5 years), while the day workers for 9.0 years $(95 \%$ CI $8.1-9.9$ years $)$ $(\mathrm{P}=0.01)$. The mean working time in the current shift was also higher among night workers compared to day workers (6.0 years - 95\% CI 5.2-6.8 years vs 4.5 years - 95\% CI 3.9-5.1 years - $\mathrm{P}=0.00)$.

The mean Body Mass Index (BMI) of night workers was $25.5 \mathrm{~kg} / \mathrm{m}^{2}\left(95 \%\right.$ CI $\left.24.8-26.1 \mathrm{~kg} / \mathrm{m}^{2}\right)$ and day workers was $25.0 \mathrm{~kg} / \mathrm{m}^{2}(95 \%$ CI $24.5-25.5$ $\mathrm{kg} / \mathrm{m}^{2}$ ), showing no statistically significant difference $(\mathrm{P}=0.25)$. A total of $52.7 \%$ reported having increased weight in the last year, being the average increase in night workers of $5.8 \mathrm{~kg}(95 \%$ CI 5.1-6.6 kg) and day workers of $5.9 \mathrm{~kg}(95 \%$ CI $5.1-6.7 \mathrm{~kg})(\mathrm{P}=0.55)$. Most had a good or very good perception of sleep quality in the last month $(67.9 \%)$ and did not feel excessive sleepiness (52.5\%). About half of those surveyed had low job satisfaction $(50.5 \%)$. In terms of diagnosed illnesses reported, $8.3 \%$ reported hypertension, $2 \%$ diabetes and $4.9 \%$ thyroid disease.

Table 2 presents the differences in the proportion of sociodemographic, lifestyle, work and health variables according to work shift. Night workers have a higher educational level, have another job, do not have diabetes and have reported longer sleep than day workers. There are also a higher number of smokers among night workers than day workers.

Table 2

Chi-square $(\chi 2)$ test of social demographic, lifestyle work and health variables by shift work.

\begin{tabular}{|c|c|c|c|c|}
\hline Variables & Categories & DW & NW & $\mathbf{p}$ \\
\hline \multicolumn{5}{|l|}{ Sociodemographic } \\
\hline \multirow[t]{2}{*}{ Age (years) ${ }^{(\mathrm{n}=446)}$} & $\leq 32^{1}$ & 146 & 81 & \\
\hline & $>33$ & 134 & 85 & 0.49 \\
\hline \multirow{2}{*}{$\underset{(\mathrm{n}=446)}{\text { Married Status }}$} & With Partner & 139 & 67 & \\
\hline & Without Partner & 141 & 99 & 0.06 \\
\hline \multirow[t]{2}{*}{$\underset{(\mathrm{n}=446)}{\text { Education Level }}$} & $\begin{array}{l}\text { Incomplete Col- } \\
\text { lege or Higher }\end{array}$ & 155 & 108 & \\
\hline & $\begin{array}{l}\text { Secondary Educa- } \\
\text { tion Completed }\end{array}$ & 125 & 58 & $0.04^{*}$ \\
\hline \multicolumn{5}{|l|}{ Lifestyle } \\
\hline \multirow[t]{2}{*}{ Smoker ${ }^{(\mathrm{n}=446)}$} & No & 264 & 144 & \\
\hline & Yes & 16 & 22 & $0.01^{*}$ \\
\hline \multirow{2}{*}{$\begin{array}{l}\text { Alchohol Con- } \\
\text { sumption }^{(\mathrm{n}=446)}\end{array}$} & No & 139 & 68 & \\
\hline & Yes & 141 & 98 & 0.08 \\
\hline \multirow{2}{*}{$\begin{array}{l}\text { Level of Physical } \\
\text { Activity }{ }^{(n=446)}\end{array}$} & Active & 176 & 95 & \\
\hline & Sedentary & 104 & 71 & 0.23 \\
\hline \multirow{2}{*}{$\underset{(\mathrm{n}=446)}{\mathrm{BMI}}\left(\mathrm{kg} / \mathrm{m}^{2}\right)$} & $\leq 24.99$ & 154 & 92 & \\
\hline & $>25$ & 126 & 74 & 0.93 \\
\hline \multicolumn{5}{|l|}{ Work } \\
\hline \multirow{2}{*}{$\underset{(\mathrm{n}=444)}{\text { Work Position }}$} & Nurse & 79 & 58 & \\
\hline & Nursing assistant & 199 & 108 & 0.15 \\
\hline
\end{tabular}




\begin{tabular}{|c|c|c|c|c|}
\hline $\begin{array}{l}\text { Duration of Work } \\
\text { in Nursing (years) } \\
(\mathrm{n}=446)\end{array}$ & $\begin{array}{l}\leq 8 \text { years }^{1} \\
>8 \text { years }\end{array}$ & $\begin{array}{l}172 \\
108\end{array}$ & $\begin{array}{l}86 \\
80\end{array}$ & $0.05^{*}$ \\
\hline $\begin{array}{l}\text { Duration of Work } \\
\text { in Current Shift } \\
\text { (years) }{ }^{(\mathrm{n}=445)}\end{array}$ & $\begin{array}{l}\leq 3 \text { years }^{1} \\
>3 \text { years }\end{array}$ & $\begin{array}{l}157 \\
122\end{array}$ & $\begin{array}{l}67 \\
99\end{array}$ & $0.00^{*}$ \\
\hline $\begin{array}{l}\text { Possesses Second } \\
\text { Job }^{(n=446)}\end{array}$ & $\begin{array}{l}\text { No } \\
\text { Yes }\end{array}$ & $\begin{array}{l}260 \\
20\end{array}$ & $\begin{array}{l}138 \\
28\end{array}$ & $0.00^{*}$ \\
\hline $\begin{array}{l}\text { Job Satisfaction } \\
(\mathrm{n}=446)\end{array}$ & $\begin{array}{l}\text { High } \\
\text { Low }\end{array}$ & $\begin{array}{l}138 \\
142\end{array}$ & $\begin{array}{l}83 \\
83\end{array}$ & 0.88 \\
\hline $\begin{array}{l}\text { Health } \\
\text { SAH }_{(\mathrm{n}=446)}\end{array}$ & $\begin{array}{l}\text { No } \\
\text { Yes }\end{array}$ & $\begin{array}{l}258 \\
22\end{array}$ & $\begin{array}{l}151 \\
15\end{array}$ & 0.66 \\
\hline$\underset{(\mathrm{n}=446)}{\text { Diabetes Mellitus }}$ & $\begin{array}{l}\text { No } \\
\text { Yes }\end{array}$ & $\begin{array}{l}271 \\
9\end{array}$ & $\begin{array}{l}166 \\
0\end{array}$ & $0.02^{*}$ \\
\hline $\begin{array}{l}\text { Thyroid disease } \\
(\mathrm{n}=446)\end{array}$ & $\begin{array}{l}\text { No } \\
\text { Yes }\end{array}$ & $\begin{array}{l}264 \\
16\end{array}$ & $\begin{array}{l}160 \\
6\end{array}$ & 0.32 \\
\hline $\begin{array}{l}\text { Excessive Sleepi- } \\
\text { ness }(>10 \text { points })\end{array}$ & $\begin{array}{l}\text { No } \\
\text { Yes }\end{array}$ & $\begin{array}{l}142 \\
138\end{array}$ & $\begin{array}{l}92 \\
74\end{array}$ & 0.34 \\
\hline $\begin{array}{l}\text { Self-reported } \\
\text { Sleep Duration } \\
\text { (hours/day) }^{(\mathrm{n}=445)}\end{array}$ & $\begin{array}{l}<7 \\
7 \mid-9 \\
\geq 9\end{array}$ & $\begin{array}{l}155 \\
92 \\
32\end{array}$ & $\begin{array}{l}57 \\
60 \\
49\end{array}$ & $0.00^{*}$ \\
\hline $\begin{array}{l}\text { DW = Day-worker } \\
\text { SAH = Systemic A } \\
{ }^{1} \text { Median Value } \\
{ }^{*} \text { p }<0.05\end{array}$ & $\begin{array}{l}\text { NW = Nig } \\
\text { erial Hyper }\end{array}$ & & & \\
\hline
\end{tabular}

When analyzing the variables married status, education level, work position, duration of work in nursing, second job, job satisfaction and diabetes associated with overweight and obesity $\left(\geq 25 . \mathrm{Kg} / \mathrm{m}^{2}\right)$, we found that more time to work in nursing and as a nursing assistant was more likely to develop overweight/obesity (Table 3).

Table 3

Logistic regression analysis predicting overweight/ obesity $\left(\mathrm{BMI} \geq 25 \mathrm{~kg} / \mathrm{m}^{2}\right) .{ }^{(\mathrm{n}=443)}$

\begin{tabular}{|c|c|c|c|c|}
\hline Variables & Categories & $\begin{array}{l}\text { OR } \\
\text { crude }\end{array}$ & $95 \%$ CI & $\mathbf{p}$ \\
\hline $\begin{array}{l}\text { Duration of Work } \\
\text { in Nursing }\end{array}$ & $\begin{array}{l}\leq 8 \text { years } \\
>8 \text { years }\end{array}$ & $\begin{array}{l}1 \\
3,34\end{array}$ & $2.24-5.00$ & 0.00 \\
\hline Work Position & $\begin{array}{l}\text { Nurse } \\
\text { Nursing assis- } \\
\text { tant }\end{array}$ & $\begin{array}{l}1 \\
1.93\end{array}$ & $1.25-2.99$ & 0.03 \\
\hline
\end{tabular}

${ }^{1}$ Adjusted by age, smoking, alcohol consumption, physical activity level, hypertension, thyroid disease, shift work and sleep duration. (Hosmer-Lemeshow $=0.77$ )
The linear regression analysis showed a greater increase in BMI for those who work the night shift compared to those working the day shift: $0.24 \mathrm{~kg} / \mathrm{m}^{2}$ and $0.15 \mathrm{~kg} / \mathrm{m}^{2}$ per year of work, respectively (Table 4). Each year of life led to an increase in BMI of 0.16 $\mathrm{kg} / \mathrm{m}^{2}$, while each year's work in nursing increased by $0.18 \mathrm{~kg} / \mathrm{m}^{2}$ per year of work.

Table 4 -

Results of linear regression analysis of body mass index $\left(\mathrm{kg} / \mathrm{m}^{2}\right)$.

\begin{tabular}{|c|c|c|c|c|}
\hline Models & $\begin{array}{l}\beta \\
\text { crude }\end{array}$ & $\begin{array}{l}95 \% \\
\text { CI }\end{array}$ & $\begin{array}{l}\beta \\
\mathbf{A d j}^{\S}\end{array}$ & $\begin{array}{l}95 \% \\
\text { CI }\end{array}$ \\
\hline [1] Age (years) ${ }^{(\mathrm{n}=446)}$ & 0.16 & $\begin{array}{l}0.12- \\
0.20^{*}\end{array}$ & $0.16^{1}$ & $\begin{array}{l}0.13 \\
0.20^{*}\end{array}$ \\
\hline $\begin{array}{l}\text { [2] Duration of work in nurs- } \\
\text { ing (years) }\end{array}$ & 0.17 & $\begin{array}{l}0.12- \\
0.22^{*}\end{array}$ & $0.18^{2}$ & $\begin{array}{l}0.13 \\
0.23^{*}\end{array}$ \\
\hline $\begin{array}{l}\text { [3] Duration of work on day } \\
\text { shift (years) }{ }^{(\mathrm{n}=279)}\end{array}$ & 0.15 & $\begin{array}{l}0.06- \\
0.25^{*}\end{array}$ & $0.15^{3}$ & $\begin{array}{l}0.06 \\
0.25^{*}\end{array}$ \\
\hline $\begin{array}{l}\text { [4] Duration of work on night } \\
\text { shift (years) }{ }_{(n=166)}\end{array}$ & 0.24 & $\begin{array}{l}0.12- \\
0.36^{*}\end{array}$ & $0.24^{4}$ & $\begin{array}{l}0.12 \\
0.37^{*}\end{array}$ \\
\hline $\begin{array}{l}\text { [5] Self-reported sleep duration } \\
\text { (hours/day) }^{(\mathrm{n}=445)}\end{array}$ & -0.01 & $\begin{array}{l}0.21- \\
0.20\end{array}$ & $0.00^{5}$ & $\begin{array}{l}0.21 \\
0.20\end{array}$ \\
\hline \multicolumn{5}{|c|}{$\begin{array}{l}{ }^{1} \mathrm{r}^{2}=0.16 /{ }^{2} \mathrm{r}^{2}=0.13 /{ }^{3} \mathrm{r}^{2}=0.05 /{ }^{4} \mathrm{r}^{2}=0.11 /{ }^{5} \mathrm{r}^{2}=0.02 \\
\text { Adjusted by smoking, physical activity level, educational level, } \\
\text { marital status and second job. } \\
{ }_{\mathrm{p}}^{\mathrm{p}}<0.05\end{array}$} \\
\hline
\end{tabular}

The coefficients of determination (the closer $r^{2}$ to 1 , the more the model is adjusted) show that increased BMI may be explained $16 \%$ by the variable age, $13 \%$ by the time working in nursing, $5 \%$ by the time working on the day shift and $11 \%$ by the time working on the night shift. Despite the low explanatory power of the variables, they are relevant, especially the difference found by day shift and night shift leading to a higher increase in BMI compared to the other variables, even from the aging process itself.

\section{Discussion}

In this study, we found that working the night shift leads to a greater increase in body mass index (BMI) compared to working during the day. The results obtained in this study were similar to studies by Niedhammer et al [23], van Amelsvoort et al [36], Geliebte et al [13] and Szpak et al [33] who found an association between weight gain and night shift.

The coefficient observed in this study was higher than that found by van Amelsvoort et al [36] in a cohort study of shift workers (who observed $0.12 \mathrm{~kg} / \mathrm{m}^{2}$ increase per year). These results show that schedules usually adopted for nursing work can affect the meta- 
bolism of workers. These findings are supported by other studies that say that the shift work is an independent risk factor for weight gain $[8,32]$.

What calls our attention in these results is the fact that we did not find a difference between the groups either in current body mass index or in the increased weight during the last year. This means that both groups had gained weight. However, as we have mentioned, working at night leads to a greater increase in BMI than the day work. A possible explanation for these results might be the difference of weight when they have started working in nursing. Night workers might be thinner than day workers at that time. In fact, the lack of this information is a limitation of the present study, since it is not a longitudinal study.

Geliebte et al [13] found that the weight increase was greater among night shift nurses compared to the diurnal nurses. However, they also have not found statistically significant differences in current weight between the two groups.

Although the results of this study have confirmed the hypothesis that night work leads to weight gain, the same did not occur in connection with the duration of sleep. The duration of reported sleep was significantly higher for those who work at night compared to those who work during the day shift.

In other words, although short sleep duration is associated with weight gain, in the present study it was not associated with night work. This finding is against expectations, particularly because it is much known the reduced sleep duration among night workers. On the other hand, the interesting side of our findings is the need to investigate metabolic changes that may be involved in weight gain in night workers. Duez and Staels [10] present that many metabolic functions have circadian rhythms, indicating a strong interaction between circadian rhythms and metabolism, a concept reinforced by the association between circadian desynchronization and increased of the incidence of metabolic disorders and increased risk of obesity.

Scheer et al [29] found that the circadian desynchronization, by itself, has an impact on levels of leptin (the hormone responsible for satiety), without influence of sleep efficiency. There is appetite stimulation with the decrease in leptin level and if it is maintained chronically, could contribute to the development of obesity [29]. Karlsson et al [19] had already put that not only reduced sleep duration may be associated with weight gain, but also the inversion of the sleep/wake cycle associated with the circadian desynchronization are associated with obesity.
It is also important to consider the inversion of the feeding schedules and as presented by SalgadoDelgado et al [28] and Ekmekcioglu and Touitou [11], which could be a possible explanation for weight gain among night workers. In a review about shift work and obesity, Antunes et al [3] present that there are epidemiological evidence of association between these two variables and that this occurs as a result of poor physiological adaptation of chronic sleepiness and/or feeding schedules on circadian abnormal, reinforcing the results found in this study.

This entire situation will be exacerbated with longer working time, a result verified in the logistic regression analysis, in which work more than eight years in the profession, raises the risk of overweight/obesity in three times more after controlling for factors confusion. The role of nursing assistant is also an important risk factor for weight gain, and nearly twice the risk as compared to nurses.

Almost 11\% had another job; however, among those who worked the night shift, $16.9 \%$ had another job. Having a second job during the day after a night shift enhances the effects of work at night, with a view to greater sleep deprivation, notes Pontes [26]. Moreover, the 12-hour shifts, often employed in hospitals, require a larger overhead when compared to working 8 hour shifts, commonly adopted in industries [20]. One can therefore consider that the workload usually observed in this category involves a paradox, since these workers, who are dedicated to caring for the health of others, have little time to care for themselves, which in itself constitutes a risk factor for health.

Despite the limitation of the results by crosssectional nature, which precludes identifying a causeeffect relationship, this study is notable for evaluating workers in real condition of work, showing that shift work is an important occupational risk factor for weight gain.

Our conclusion is there is likely to be an increase in body weight with age and with years of work in the profession. In addition, working at night is associated with a weight gain greater than during the day.

Funding - Support: CNPq-309441/2007-2

Conflicts of Interest: The authors declare no conflict of interest.

\section{References}

[1] Obesity: preventing and managing the global epidemic. Report of a WHO consultation. World Health Organ Tech Rep Ser. 2000;894:i-xii, 1-253. 
[2] Admi H, Tzischinsky O, Epstein R, Herer P, Lavie P. Shift work in nursing: is it really a risk factor for nurses' health and patients' safety? Nurs Econ. 2008 Jul-Aug;26(4):250-7.

[3] Antunes LC, Levandovski R, Dantas G, Caumo W, Hidalgo MP. Obesity and shift work: chronobiological aspects. Nutr Res Rev. 2010 Jun;23(1):155-68.

[4] Bjorvatn B, Sagen IM, Oyane N, Waage S, Fetveit A, Pallesen $\mathrm{S}$, et al. The association between sleep duration, body mass index and metabolic measures in the Hordaland Health Study. J Sleep Res. 2007 Mar;16(1):66-76.

[5] Brown DL, Feskanich D, Sanchez BN, Rexrode KM, Schernhammer ES, Lisabeth LD. Rotating night shift work and the risk of ischemic stroke. Am J Epidemiol. 2009 Jun $1 ; 169(11): 1370-7$

[6] Canini SR, Moraes SA, Gir E, Freitas IC. Percutaneous injuries correlates in the nursing team of a Brazilian tertiary-care university hospital. Rev Lat Am Enfermagem. 2008 SepOct;16(5):818-23.

[7] Chaput JP, Lord C, Aubertin-Leheudre M, Dionne IJ, Khalil A, Tremblay A. Is overweight/obesity associated with short sleep duration in older women? Aging Clin Exp Res. 2007 Aug;19(4):290-4

[8] Croce N, Bracci M, Ceccarelli G, Barbadoro P, Prospero E Santarellia L. [Body mass index in shift workers: relation to diet and physical activity]. G Ital Med Lav Ergon. 2007 JulSep;29(3 Suppl):488-9.

[9] Dekkers JC, van Wier MF, Hendriksen IJ, Twisk JW, van Mechelen W. Accuracy of self-reported body weight, height and waist circumference in a Dutch overweight working population. BMC Med Res Methodol. 2008;8:69.

[10] Duez H, Staels B. Rev-erb-alpha: an integrator of circadian rhythms and metabolism. J Appl Physiol. 2009 Dec;107(6):1972-80.

[11] Ekmekcioglu C, Touitou Y. Chronobiological aspects of food intake and metabolism and their relevance on energy balance and weight regulation. Obes Rev. 2011 Jan;12(1):14-25.

[12] Fischer FM. Fatores individuais e condições de trabalho e de vida na tolerância ao trabalho em turnos, in: Fischer FM, Moreno CRC, Rotenberg L (org). Trabalho em turnos e noturno na sociedade 24 horas. Atheneu: São Paulo, 2004, pp 65-76.

[13] Geliebter A, Gluck ME, Tanowitz M, Aronoff NJ, Zammit GK. Work-shift period and weight change. Nutrition. 2000 Jan;16(1):27-9.

[14] Grandjean E. Fitting the task to the man; a textbook of occupational ergonomics. Taylor \& Francis: London, UK, 1988.

[15] Ha M, Park J. Shiftwork and metabolic risk factors of cardiovascular disease. J Occup Health. 2005 Mar;47(2):89-95.

[16] Horne J. Short sleep is a questionable risk factor for obesity and related disorders: statistical versus clinical significance. Biol Psychol. 2008 Mar;77(3):266-76.

[17] Humphries JD. Workplace debt: sleep loss. Creat Nurs. 2009;15(1):23-7.

[18]Johns MW. A new method for measuring daytime sleepiness: the Epworth sleepiness scale. Sleep. 1991 Dec;14(6):540-5.

[19] Karlsson B, Knutsson A, Lindahl B. Is there an association between shift work and having a metabolic syndrome? Results from a population based study of 27,485 people. Occup Environ Med. 2001 Nov;58(11):747-52.

[20] Knauth P. Innovative worktime arrangements. Scand J Work Environ Health. 1998;24 Suppl 3:13-7.

[21]Lopez-Garcia E, Faubel R, Leon-Munoz L, Zuluaga MC, Banegas JR, Rodriguez-Artalejo F. Sleep duration, general and abdominal obesity, and weight change among the older adult population of Spain. Am J Clin Nutr. 2008 Feb;87(2):310-6.
[22] Moreno CR, Louzada FM, Teixeira LR, Borges F, LorenziFilho G. Short sleep is associated with obesity among truck drivers. Chronobiol Int. 2006;23(6):1295-303.

[23] Niedhammer I, Lert F, Marne MJ. Prevalence of overweight and weight gain in relation to night work in a nurses' cohort. Int J Obes Relat Metab Disord. 1996 Jul;20(7):625-33.

[24] Park YJ, Lee WC, Yim HW, Park YM. [The association between sleep and obesity in Korean adults]. J Prev Med Public Health. 2007 Nov;40(6):454-60.

[25] Patel SR, Malhotra A, White DP, Gottlieb DJ, Hu FB. Association between reduced sleep and weight gain in women. Am J Epidemiol. 2006 Nov 15;164(10):947-54.

[26] Pontes Z. O trabalho noturno do enfermeiro: busca de significados sobre o repouso antes, durante e após o plantão. Rev Bras Enf 1992; 45(1): 80-87.

[27] Robertson IT, Cooper CL, Williams J, Williams J. The validity of the occupational stress indicator. Work and Stress 1990; 4(1): 29-39.

[28] Salgado-Delgado R, Angeles-Castellanos M, Saderi N, Buijs RM, Escobar C. Food intake during the normal activity phase prevents obesity and circadian desynchrony in a rat model of night work. Endocrinology. 2010 Mar;151(3):1019-29.

[29] Scheer FA, Hilton MF, Mantzoros CS, Shea SA. Adverse metabolic and cardiovascular consequences of circadian misalignment. Proc Natl Acad Sci U S A. 2009 Mar 17;106(11):4453-8.

[30] Singh M, Drake CL, Roehrs T, Hudgel DW, Roth T. The association between obesity and short sleep duration: a population-based study. J Clin Sleep Med. 2005 Oct 15;1(4):357-63.

[31] Staels B. When the Clock stops ticking, metabolic syndrome explodes. Nat Med. 2006 Jan;12(1):54-5; discussion 5.

[32] Suwazono Y, Dochi M, Sakata K, Okubo Y, Oishi M, Tanaka $\mathrm{K}$, et al. A longitudinal study on the effect of shift work on weight gain in male Japanese workers. Obesity (Silver Spring) 2008 Aug;16(8):1887-93.

[33] Szpak A, Jamiolkowski J, Witana K. Overweight and obesity and their determinants among men from Podlasie region in the years 1987-1998. Rocz Akad Med Bialymst. 2005;50 Suppl 1:245-9.

[34] Tenkanen L, Sjoblom T, Harma M. Joint effect of shift work and adverse life-style factors on the risk of coronary heart disease. Scand J Work Environ Health. 1998 Oct;24(5):351-7.

[35] Tuomi k, Ilmarinen J, Jahkola A, Katajarinne I, Tulkki A. Índice de capacidade para o trabalho. Traduzido e adaptado para a língua portuguesa: Frida FM et al, 2005. São Carlos: Instituto Finlandês de Saúde Ocupacional/ EdUFSCAR.

[36] van Amelsvoort LG, Schouten EG, Kok FJ. Duration of shiftwork related to body mass index and waist to hip ratio. Int J Obes Relat Metab Disord. 1999 Sep;23(9):973-8.

[37]Zverev YP, Misiri HE. Perceived effects of rotating shift work on nurses' sleep quality and duration. Malawi Med J. 2009 Mar;21(1):19-21. 